\title{
Social Mapping for Human Resource Development Planning in Desa Losari Sumowono District, Semarang Regency
}

\author{
Imam Anas Hadi \\ Universitas Darul Ulum Islamic Centre Sudirman (UNDARIS) Semarang, Indonesia \\ email: imamhadianas309@gmail.com
}

\begin{abstract}
This research aims to discover a social map in Losari Village, Sumowono District, Semarang Regency and to find out the use of social mapping for human resource development planning in Losari Village, Sumowono District Semarang Regency. This research uses descriptive qualitative research to describe the research object and uses observation, interviews, and documentation techniques to obtain data. The researcher used the Miles and Huberman technique regarding the data analysis, namely data reduction, data presentation, and drawing conclusions and verification. The mapping results know social problems, including socio-cultural, economic, and infrastructure problems. Then it can uncover the natural and human potential in Losari village, the potential of human resources in the form of farmers, and improve education in Losari Village. No less important are actors who play a role in social relations. Mapping benefits can be obtained first, the actual area of a village, the geographical location of the village and the boundaries of the area, and the village's history. Both the conditions and characteristics of the community, the potential and problems that exist in the village emerged. The third is social mapping to develop or create programs according to the potential and problems that exist in the region.
\end{abstract}

Keywords: Social Mapping, Development Planning, Human Resources.

\begin{abstract}
ABSTRAK
Tujuan penelitian ini adalah untuk mengetahui peta sosial di Desa Losari Kecamatan Sumowono Kabupaten Semarang dan untuk mengetahui pemanfaatan pemetaan sosial untuk perencanaan pengembangan sumber daya manusia di Desa Losari Kecamatan Sumowono Kabupaten Semarang. Penelitian ini menggunakan jenis penelitian deskriptif kualitatif untuk menggambarkan objek penelitian, serta menggunakan teknik pengumpulan
\end{abstract}


data berupa teknik observasi, wawancara, dan dokumentasi untuk mendapatkan data. Mengenai teknik analisis data, peneliti menggunakan teknik Miles dan Huberman yaitu reduksi data, penyajian data, dan penarikan kesimpulan dan verifikasi. Hasil pemetaan yaitu mengetahui permasalahan sosial, meliputi masalah sosial-budaya, masalah ekonomi dan masalah infrastruktur. Kemudian dapat mengetahui potensi alam dan manusia yang ada di desa Losari, Potensi SDM berupa petani dan peningkatan pendidikan yang ada di Desa Losari. Takkalah penting yaitu aktor yang berperan dalam proses relasi sosial. Pemanfaat pemetaan dapat didapatkan pertama wilayah yang sesungguhnya dari suatu desa, letak geografis desa dan batas-batas wilayah serta sejarah desa. Kedua kondisi dan karakteristik masyarakat, muncul potensi dan permasalahan yang ada di desa. Ketiga pemetaan sosial untuk menyusun atau membuat program sesuai dengan potensi serta masalah yang ada pada wilayah.

Kata Kunci: Pemetaan Sosial, Perencanaan, Pengembangan Sumber Daya Manusia

\section{INTRODUCTION}

The efforts to realize community welfare in development urge the necessity to have poverty alleviation efforts by socializing the importance of education and skills. It is urgent to improve the quality and community participation. Efforts are made to develop and help the community deal with social problems. For the sake of realizing social welfare, the government must make several efforts, such as what has been stated in the Qur'an as follows: "...and (remember) when Abraham prayed: "O my Lord! Make this country a safe country, and give sustenance of fruit to residents who believed in Allah and the Last Day. (QS. Al-Baqarah: 126 )" (Rida, 20).

Surah al-Baqarah explains the nation's vision to fulfill all the basic needs of its inhabitants and in line with efforts to improve the quality of its human beings. By improving the quality of its human resources, the development process will be more straightforward and develop towards a better level. The development in question is an effort in consciously planned growth and change by a nation, state, and government towards modernity to develop the nation (Siagian, 2013: 41). Professional human resources are expected to use management in effective change to benefit living in the future. It is in line with the new paradigm of National education, which refers to institutional management by professional Human Resources, which is one of the main pillars of the success of educational organizations in producing quality resources (Rokhmiyati, 2018: 234).

Indonesia is a country of law whose normative resource wealth is controlled by the state and managed for community welfare (Article 33 by the 1945 Constitution) and provides benefits to society of the present without compromising the future generations (Sutrisno, 2014: 2). The natural resources are utilized to the maximum extent for the prosperity of the people while still paying attention to sustainability, and environmental functions (Wijaya, 2016: 150). Development in a country requires primary assets called natural resources, and man (human resources). Both of these resources are important in determining the success of a development (Notoatmodjo, 2003: 2). 
Based on its geographical location, Losari Village is a village located at Mount Ungaran, Semarang Regency, Central Java; most people are farmers (Damsar \& Indrayani, 2016: 72). It is undeniable that the people in Losari Village have social problems; like other village communities, Losari Village also has quite complex problems. One of them is that children drop out of school and do not continue their compulsory 12 years education. It is due to people's thinking that schools do not guarantee to meet economic needs, besides the low interest of parents in education.

The low level of education in Losari Village is lagging in education because almost these children only receive elementary school education, not even a few have dropped out of school or did not graduate (interview with SID village staff). It is a significant problem in managing the potential of human resources. This condition hinders the social mobility and soft skills of the population. In addition to the potential of human resources, Losari Village is also rich in natural potentials, such as agricultural products.

Social problems due to the low level of education must be addressed through development intervention programs of the regional government. In the context of social development in the region, peegunungan social engineering (social engineering) is necessary. Social engineering itself is a deliberate, conscious, planned, systematic, and gradual effort to increase the quality of life in society. Therefore, social development is directly related to improving the quality of human resources and positively impacts various sectors. This development field has a strategic dimension to be prioritized (Kusnadi, 2013:37).

Efforts are made to support government development in managing natural potential; first, developing and improving human resources is necessary. It is possible by employing socialization to educate the community sustainably in various ways, both formally and informally, such as participating in various training adapted to their abilities and needs and human dignity socially.

Human resources that have developed or advanced can contribute to community development. In the sociological aspect, it can be said that if a person gets or improves his education, he will also increase his social status in the surrounding community-the contribution of human resources in the context of increasing development in the development aspect. For example, the training that will be carried out for the people of Losari Village is to make snacks from agricultural products and serve as unique souvenirs of Losari Village. Indirectly, the training can provide income or community income and increase cooking skills. In addition, there is also training in the management of the culinary and education fields in the Maju Rahayu PKBM (Community Learning Activity Center) program. So the government of Sumowono District, especially Losari Village, encourages the community to improve education, both formal and non-formal, to improve the development of each individual and family.

The importance of planning human resource development is an initial basis in solving social problems in Losari Village, Semarang Regency. The first step is to develop human resource development through social mapping. Social mapping is defined as a systematic process. Public depiction involves collecting data and information about the community, including profiles, social issues, and needs (Hasim \& Remiswal, 2009: 159).

Social mapping itself has been carried out in Losari Village; this is indicated by the existence of the RPJMDes (Village Medium-Term Development Plan) as the result of social mapping. The contents of this RPJMDes also contain several potentials and problems in the village; there is even a 
program to answer the problems in Losari Village. However, these programs have not been implemented until now and have not significantly impacted the community, especially related to human resource development.

The importance of proper identification in mapping so that the potentials that emerge from the mapping results can support the development of the community's welfare. The mapping process that involves community participation can begin from the government bureaucracy, namely the kelurahan because the kelurahan is the closest government that often interacts with the community. In addition, the kelurahan is one of the policy implementers from the central government and a forum for deliberation on the community development planning in its environment.

Social mapping can be said to be a systematic community depiction process and involves collecting data and information about the community, including village profiles and social problems that exist in the community (Suharto, 2014:81). Thus, the benefits of social mapping are usually in the form of a regional map concerning the community characteristics or social problems. For example, the number of conflict-prone residents, the poor, and as much other information as possible in a specific area can be used as material for making the best decisions in the development process (Hasim \& Remiswal, 2009).

This research tries to examine human resource development planning through the social mapping method. Therefore, some things underlie the importance of this research, namely, first, social mapping is seen as one approach in handling problems that exist in Losari Village. Second, the importance of social mapping in empowering the potential in Losari Village, Sumowono District, Semarang Regency to improve community welfare, one of which is human resource planning. Therefore, the author is intrigued in conducting a study entitled "Social Mapping for Human Resource Development Planning in Losari Village, Sumowono District, Semarang Regency."

\section{METHOD}

Researchers used qualitative descriptive research to describe the research object and used data collection techniques of observation, interviews, and documentation techniques to obtain data. The researcher used the Miles and Huberman technique regarding the data analysis, namely data reduction, data presentation, and drawing conclusions and verification.

\section{RESULTS AND DISCUSSION}

\subsection{Social Mapping for Human Resource Development Planning}

Human resource development is one of the development processes in which the implementation of the development has two main assets, namely natural resources and human resources. Of these two main assets, human resources are more important than natural resources. Because of how abundant natural resources are, it will certainly be in vain without the ability of good human resources to process them. Meanwhile, social mapping is an activity carried out to understand the social conditions of local communities. 
Other than knowing the community's basic needs, social mapping is also carried out to determine several aspects. For example, it discovers the potential of natural or human resources and social capital of the community or social networks, identifies actors who play a role in their activities and existence in the program and identifies problems felt by the community to improve living standards. These two things are closely related because proper social mapping is needed to develop valuable human resources. The forms that are mapped are, among others:

(1) Actors who play a role in the process of social relations. Some people in Losari Village are considered to have a good social position and are certainly very influential in the community, especially regarding making a policy for the benefit of the village. In this case, the people who play a role in social relations are the Village Head, where he always protects every citizen and decide every program that will be legalized. Then, the Village Secretary is trusted to manage, carry out administrative functions and village programs.

Next, the role of Community Leaders is also crucial in policymaking because a Community Leader has an interest in providing considerations in program implementation and as a mediator between the village government and the community. A religious figure also always fosters religious people to maintain harmony between people. Furthermore, village institutions, namely the BPD and LKM, have a primary function. The BPD is the supervisor in program implementation, and the LKM is the driving force for empowered communities.

(2) Social problem. The following form of mapping is the social problems in Losari Village. Each village must have different problems. It looks like a prosperous society; it is undeniable that Losari Village also has social problems, including socio-cultural, economic, and infrastructure issues. A crucial problem for coastal communities is the low level of education. It also applies to the Losari Village community, the coastal community. In addition to the low level of education, the people of Losari Village also have a very dense population. The following are the problems of Losari Village, which include: a) Socio-cultural problems, b) Economic problems, and c) Infrastructure problems.

(3) The potential of Losari Village. Each village certainly has different potentials. In this case, Losari Village groups several potentials: natural potential, human resource potential, infrastructure potential, and social capital potential. Known as a farming community, it has natural potential in land products. Then the potential of human resources, namely farmers, seeing from their natural potential in the form of natural products they work. Then, the education level, most of which have graduated from elementary school, is expected to follow the program from PKBM Maju Rahayu in the pursuit program packages A, B, and C, which are expected to balance the potential of nature. Before cultivating natural potential, improving the quality of human resources is much more critical.

The potential for social capital is in the form of social networks (relationships) between farmers and traders to foster cooperation. Moreover, the potential for social networks with government agencies is to improve education and training to improve the quality of human resources in Losari Village.

(4) Social mapping approach. To find out how social mapping is, of course, by using suitable methods and techniques. In this case, the author uses a rapid appraisal method. This method is fast and inexpensive to collect data and information regarding geographic conditions, socio- 
economic conditions, and views and input from the community and stakeholders. Following are the quick monitoring methods, namely:

a) Key Informant Interview. A series of open-ended questions were prepared in advance, and certain people believed to have experience and knowledge of social mapping were determined. There are social problems and the actual situation. The key informants are the Village Head, Village Secretary, Head of Government, Chair and Members of the PKK, Religious Leaders, and Community Leaders. From several vital informants, of course, can get much information that the author believes. However, it is undeniable that this crucial informant interview was beneficial for the writer. The lack of written village data, village program reports, the RPJMDes has not been made, and so on. Make the author make the most of this method.

b) Focus Group Discussion. On this occasion, the author had time to follow the routine of PKK women every Saturday. In this forum, of course, there will be FGDs that discuss what is needed, welfare issues, etc. The discussion, which 8-12 members attended, recorded the discussion process and then provided feedback on the results of their observations, usually in the form of solutions or plans to resolve problems. During routine PKK women, Losari Village officials always create discussion forums in making programs or solving problems.

c) Community Group Interview. In this case, the interviewer conducted the interview carefully, based on the interview guide prepared in advance. All community members asked for this interview, and it was conducted in an open meeting. As explained by the Head of Losari Village, it is undeniable that the community's aspirations with a heart-to-heart interview will resolve the problem more quickly. However, on several occasions in the forum meeting with residents, there are obstacles such as the lack of community participation even though his presence will solve for the common good. Few people do not want to do interviews because they know nothing. However, information from anyone will certainly take maximum results.

d) Live Observation. Direct observation will undoubtedly be more relevant to find out the local community's state in field visits. The collection of data in geographical conditions, socioeconomic conditions, knowing existing sources, and social interactions result from direct observation. However, the author has not had the opportunity to participate in program activities that support human resources development because it took place last February 2020. Fortunately, social interaction with PKK members and the community who participated in the program was enough to provide an overview to the author.

e) Small Survey (Mini Survey). The author's way of collecting information is the application of closed-ended questions in limited locations such as village halls. Interviews with the village head and several village staff support the minimal written data. So this tiny survey is one of the rapid monitoring methods considered adequate as the information that can be trusted.

\subsection{Utilization of Social Mapping for Human Resource Development Planning}

The benefits of social mapping then produce several programs, which follow the existing social problems and the potential to be developed. Talking about the development, it usually relates to an increase and ability. Human resource development is based on that every individual 
needs knowledge, skills, and abilities to develop. In this case, the development of human resources can be realized through education and training. The methods in developing human resources include education and training methods.

1) Educational Method. Education is the most critical method in developing human resources due to changes in behavior and mindset. In addition, the primary purpose of education is a description of knowledge, attitudes, actions, and appearance. The following are programs related to education, namely PKBM (Center for Community Learning Activities) Maju Rahayu. PKBM is an institution formed by the community engaged in education. In this case, Losari Village presents PKBM Maju Rahayu as a center for community learning activities, in which there is a program to improve human resources in Losari Village. PKBM Maju Rahayu is here as a forum for the community to improve education in Losari Village. The programs presented in PKBM Maju Rahayu, namely pursuing package $A$, pursuing package $B$, pursuing package $C, P A \cup D$, and literacy.

2) Training Method. The training method chosen is based on the needs coming from the interests of organizations or agencies, government and non-government, and the needs of each individual. So, in this case, it is necessary to pay attention to the training, which concerns the implementation time, the number of participants, the individual background, and other matters concerning the individual (Priansa, 2018:102). The following is a form of training, together with the Department of Cooperatives and MSMEs, is in the culinary field.

Knowing the potential in Losari Village, namely agricultural products, of course, should not be wasted. This program will undoubtedly train creativity to improve the quality of human resources in Losari Village. This program involved social networking with the Department of Cooperatives and SMEs. The program, which was held on February 11-15, 2020, took place in the display building, formerly the building where PNPM Mandiri was based, according to a statement from Mrs. Yatinah as a participant who took part in the program. The organizers of this training are government agencies, namely the Cooperatives and MSMEs Service, which collaborates with Losari Village to train community creativity.

The effort carried out by the Cooperatives and UMKM Service is in the form of a training program in processing agricultural products in the culinary field (food). What is meant here is making martabak from onclang, chips from cassava, and kimpul. Participants who took part in this training were drawn from each RW selected by the local RW and the Losari Village PKK members. The number of participants who took part in the training was 20 participants, all of whom were housewives who were expected to be able to equip their businesses to improve the family's economy. The village icon, known for its abundant fish products, is also expected to become a typical souvenir of Losari village.

\section{CONCLUSION}

Social mapping for human resource development planning based on data obtained from the field, the HR development program will provide optimal benefits with the social mapping method, collecting data and information, in which there are profiles and social problems, of course, can give birth to accessible and appropriate solutions according to the conditions of the Losari village community. The forms that are mapped are, by involving influential actors and institutions in the village, the potential of both nature and humans in the village, and understanding the social 
problems in the village. The mapping result is knowing social problems, including socio-cultural problems, economic problems, and infrastructure problems. Then can find out the natural and human potential in Losari village, namely agricultural and plantation products. Potential human resources in agriculture and plantations and improving education in Losari village. No less important are actors who play a role in social relations.

The use of social mapping for planning human resource development social mapping has influenced the people of Losari Village regarding the development of human resources. Because with the mapping, the problems and needs of the Losari Village community can be seen. In this case, to develop human resources, there are two methods, namely education, and training. It resulted in two programs that have been implemented, namely in the field of education, there is the PKBM Maju Rahayu program. In the training field, there is training on processing marine products based on natural potential in Losari Village. In this case, it is a relationship with the Cooperatives and UMKM Service to increase creativity and productive efforts to empower the community. Several programs that have been implemented have made social mapping very important and can provide benefits in the empowerment process, among others, first, to know the actual area of a village. Thus, the village's geographical location, the boundaries of the area, and the history of the village will be known. Second, to find out the conditions and characteristics of the community, where the potential and problems that exist in the village will appear. It is hoped that there will be no misunderstanding between program providers and program recipients later. Finally, social mapping helps compile or make programs according to the potential and problems in the area.

\section{REFERENCES}

Achmad Fahrudin, Muhammad Arsyad Al-Amin, Taryono Kodiran, dkk. (2015). Pemetaan Sosial (social mapping) di Wilayah Pesisir Kabupaten Gresik. Working Paper PKSPL-IPB, 1-45.

Anggi, Raden dan Nanu. (2020). Pemetaan Sosial Pada Pengrajin Bambu di Desa Parung Sari Kabupaten Karawang. Vol.06. Nomor 02.139-148.

Bambang Rudito \& Melia Famiola. (2013). Social Mapping. Bandung: Rekayasa Sains.

Damsar \& Indrayani. (2016). Pengantar Sosiologi Pedesaan. Jakarta: Kencana.

Danim, S. (2002). Menjadi Peneliti Kualitatif. Bandung: Pustaka Setia.

Dumasari. (2014). Dinamika Pengembangan Masyarakat Partisipatif. Yogyakarta: Pustaka Pelajar.

Hasim \& Remiswal. (2009). Community Development Berbasis Ekosistem (Sebuah Alternatif Pengembangan Masyarakat). Jakarta: Diadit Media.

Jamaludin, A. N. (2015). Sosiologi Perdesaan. Bandung: CV Pustaka Setia.

Komariah, D. S. (2017). Metodologi Penelitian Kualitatif. Bandung: Alfabeta.

Kusnadi. (2013). Membela Nelayan. Yogyakarta: Graha Ilmu.

M. Umar Maya Putra \& Ami Dilham. (2017, April 7). Pemetan Sosial Ekonomi Masyarakat Kecamatan Dumai Timur (Studi Kasus: Bukit Timah). Wira Ekonomi Mikroskil, 7, 1-8.

Mardikanto, T. (2015). Pemberdayaan Masyarakat dalam Perspektif Kebijakan Publik Edisi Revisi. Bandung: Alfabeta. 
Moleong, L. J. (2004). Metodologi Penelitian Kualitatif. Bandung: Rosdakarya.

Moleong, L. J. (2007). Metodologi Penelitian Kualitatif. Bandung: PT Remaja Rosdakarya.

Muhadjir, N. (2000). Kebijakan Perencanaan Sosial Pengembangan Sumber Daya Manusia Telaah Cross Discipline. Yogyakarta: Bigraf Publishing.

Muhammad Fauzan Firdaus, Hamdan Fauzi, \& Asyisyifa. (2018, November 2). Pemetaan Sosial (social mapping) Masyarakat Sekitar KHDTK UNLAM di Desa Mandiangin Barat. Sy/va Scienteae, 1, 92-103.

Mulyana, D. (2001). Metodologi Penelitian Kualitatif, Paradigma Baru IImu Komunikasi, dan IImu Sosial Lainnya. Bandung: Remaja Rosdakarya.

Notoatmodjo, S. (2003). Pengembangan Sumber Daya Manusia. Jakarta: PT. Asdi Mahasatya.

Nugroho, R. (2014). Kebijakan Sosial untuk Negara Berkembang. Yogyakarta: Pustaka Pelajar.

Priansa, D. J. (2018). Perencanaan dan Pengembangan Sumber Daya Manusia. Bandung: Alfabeta.

Rokhmiyati, Sri, (2018 Desember 2). Konsep Manajemen Sumber Daya Manusia dalam Kelembagaan Islam, Jurnal Academia IAIN Salatiga 2018, p-ISSN: 2548-5857; e-ISSN: 25487124 Vol. 3, No. 2 . h. 231-252.

RI, D. (1989). Kamus Besar Bahasa Indonesia. Jakarta: Balai Pustaka.

Rida. (2014). Al-Qur'an dan Terjemahannya. Bandung: IKAPI.

Setu Mulyadi, A. M. Heru Basuka \& Hendro Prabowo. (2019). Metode Penelitian Kualitatif dan Mixed Method. Depot: PT. RajaGrafindro Persada.

Siagian, S. P. (2013). Manajemen Sumber Daya Manusia. Jakarta: Bumi Aksara.

Silalahi, U. (2009). Metode Penelitian Sosial. Bandung: PT. Refika Aditama.

Sinaga, D. (2016, November 3). Hubungan Sumber Daya Manusia \& Sosial Budaya dengan Tingkat Kesejahteraan Masyarakat di Kecamatan Senembah Tanjung Muda Hulu Kabupaten Deli Serdang. Sosiohumaniora, 18, 218-226.

Sugiyono. (2015). Motode Penelitian Kuantitatif Kualitatif dan R\&B. Bandung: Alfabeta.

Suharto, E. (2014). Membangun Masyarakat Memberdayakan Rakyat Kajian Strategis Pembangunan Kesejahteraan Sosial dan Pekerjaan Sosial. Bandung: PT Refika Aditama.

Sukaris. (2019). Social Mapping sebagai Landasan Perencanaan Pemberdayaan Masyarakat Berkelanjutan. Riset Entrepreneurship, 2, 51-60.

Sutrisno. 2014. Manajemen Sumber Daya Manusia. Cetak Ke Enam. Jakarta: Pranada Media Group.

Tesoriero, J. I. (2016). Community Development Alternatif Pengembangan Masyarakat di Era Globalisasi. Yogyakarta: Pustaka Pelajar.

Sutresno, Endang, (2014 Januari 1). Implementasi Sumberdaya Pesisir Berbasis Pengelolaan Wilayah Pesisir Secara Terpadu untuk Kesejakteraan Nelayan (Studi Pedesaan Nelayan Cangkol Kelurahan Lemahwungkuk Kecamatan Lemahwungkuk Kota Cerebon), jurnal dinamika hukum Universitas swadaya gunung jati cerebon jawa barat, Volume. 14 No. 1 Januari h. 2-12.

Totok Mardikanto \& Poerwoko Soebiato. (2015). Pemberdayaan Masyarakat dalam Perspektif Kebijakan Publik Edisi Revisi. Bandung: Alfabeta.

Wakerkwa, O. (2016). Peranan SDM dalam Meningkatkan Pembangunan Masyarakat di Desa Unbanue Kecamatan Pirime Kabupaten Lanny Jaya. Holistik, 2-20.

Wijaya, Etistika Yuni, (2016). Transformasi pendidikan abad 21 sebagai tuntutan pengembangan sumber daya manusia di era global." Prosiding Seminar Nasional Pendidikan Matematika. vol. 1. No. 26. 120-141. 